\title{
Comparison of Six Stylosanthes Cultivars and Digitaria Milanjiana in the Humid Mountain Region of Puerto Rico ${ }^{1}$
}

\author{
J. Vélez-Santiago and J. A. Arroyo-Aguilü ${ }^{2}$
}

\begin{abstract}
Five Stylosanthes guianensis cultivars (Fine Stem, Endeavour, Schofield, USDA PI 361877, and USDA PI 279603), Stylosanthes gracilis USDA PI 261266, and Digitaria milanjiana USDA PI 299699 were grown in small replicated plots at the Corozal Substation in the humid mountain region. All legumes were established in a period of 134 days and nodulated freely. The swards were harvested every 45 (9 cuttings) and 65 days ( 6 cuttings) at $20 \mathrm{~cm}$ above ground level, respectively. Forage yields and chemical composition were measured in each plot. Subsequently the same 65-day cutting interval swards were subjected to 5 additional cuttings, whereas the 45-day swards were substituted by a 79-day interval and 4 cuttings. D. milanjiana outyielded the 6 stylos in dry forage at the 3 cuttings intervals.

Highest yielder among the stylos was cultivar Fine Stem, which produced total dry forage yields of $18,522,18,936$, and $11,329 \mathrm{~kg}$ per ha in $395-, 390-$, and 316-day periods at 45-, 65-, and 79-day harvest intervals, respectively. At 45-day intervals, cultivar Fine Stem yielded more crude protein than the rest of the stylo cultivars. There was no difference in protein yields between cultivar Fine Stem and $D$. milanjiana at the 45- and 65-day harvest intervals. Stylo cultivars and $D$. milanjiana produced similar crude protein yields at the 79 -day intervals. The stylo cultivars were higher in nitrogen, calcium and magnesium contents than $D$. milanjiana at all harvest intervals.
\end{abstract}

\section{INTRODUCTION}

During the last 25 years, many tropical forage legumes have been introduced by the Agricultural Experiment Station of the University of Puerto Rico. Tropical Kudzu [Pueraria phaseoloides (Roxb) Benth] and Stylosanthes guianensis cultivar Endeavour are the most promising under either grazing or cutting management $(12,14)$.

Numerous studies in Australia (4, 5, 6, 7, 8, 9), in South America (1, 10) and in Puerto Rico (14) have shown that the genus Stylosanthes has great potential as a forage crop, either alone or in association with a grass. In Australia, seeds of cultivars Endeavour and Schofield are sold commercially.

Recently, Vélez-Santiago et al. (14) reported that $S$. guianensis cultivar Endeavour produced 10,047 and 1,674 kg per ha per yr of dry forage (DF) and crude protein (CP), respectively, without $\mathrm{P}$ and $\mathrm{K}$ fertilization, when harvested at about 80 days of growth. In view of the promising perform-

${ }^{1}$ Manuscript submitted to Editorial Board November 4, 1983.

${ }^{2}$ Associate Agronomist, Agronomy and Soils Department and Nutritionist, Animal Industry Department, Agricultural Experiment Station, University of Puerto Rico, Corozal and Río Piedras, P.R., respectively. Appreciation is expressed to Mr. José E. RodriguezArroyo for his valuable help in collecting most of the field data. 
ance of this genus, further accessions of stylos were introduced in 1976 and grown in the legume nursery at the Corozal Substation in the humid mountain region of Puerto Rico. After 1 year of observations, the best ones were selected for a field plot experiment.

This study reports the performance of six stylo accessions in pure stands, as compared to D. milanjiana USDA PI 299699, when cut at 45-, 65-, and 79-day intervals.

\section{MATERIALS AND METHODS}

The cultivars were evaluated in small plots at the Corozal Substation (lat. $66^{\circ} 23^{\prime} \mathrm{E}$, long. $18^{\circ} 22^{\prime} \mathrm{N}$, and elevation of $210 \mathrm{~m}$ ). The soil was a Corozal clay (Ultisol) with $11 \mathrm{p} / \mathrm{m} \mathrm{P}, 86 \mathrm{p} / \mathrm{m} \mathrm{K}$, and a $\mathrm{pH}$ of approximately 5.3 in the top $20-\mathrm{cm}$ layer. No lime was applied during the experimental period.

TABLE 1.-Identification of 6 forage legumes and 1 forage grass

\begin{tabular}{lccll}
\hline \multicolumn{1}{c}{ Species $^{1}$} & USDA PI $^{2}$ & PRPI $^{3}$ & Other & \multicolumn{1}{c}{ Origin } \\
\hline $\begin{array}{l}\text { Stylosanthes guianensis } \\
\text { cultivar Fine stem }\end{array}$ & - & - & IRFL-1416 & Brazil \\
$\begin{array}{l}\text { Stylosanthes guianensis } \\
\text { cultivar Endeavour }\end{array}$ & - & - & Q-8558 & Guatemala \\
$\begin{array}{l}\text { Stylosanthes guianensis } \\
\quad \text { cultivar Schofield }\end{array}$ & - & - & IRFL-1413 & Brazil \\
$\begin{array}{l}\text { Stylosanthes guianensis } \\
\text { Stylosanthes guianensis }\end{array}$ & 361877 & 13265 & - & Philippines \\
$\begin{array}{l}\text { Stylosanthes gracilis } \\
\text { Digitaria milanjiana }\end{array}$ & 279603 & 13264 & - & China \\
\hline
\end{tabular}

${ }^{1}$ This material was introduced through the S-9(H-94) research project.

${ }^{2}$ United States Department of Agriculture plant introduction number.

${ }^{3}$ University of Puerto Rico Agricultural Experiment Station plant introduction number.

${ }^{4}$ Indian River Florida plant introduction number.

${ }^{5}$ Queensland plant introduction number.

Table 1 identifies the six forage legumes and the forage grass. Sixmonth-old, locally-collected seed with a mean $80 \%$ germination, according to glasshouse tests, were used. Before planting, the seeds were scarified in concentrated sulfuric acid for $6 \mathrm{~min}$, and rinsed in running water for $10 \mathrm{~min}$. Plots were handseeded at a rate of $6 \mathrm{~kg} / \mathrm{ha}$ December 28, 1977. Sprinkle irrigation was applied daily until the plants were established, but not thereafter.

The experimental layout was a randomized block, split-plot design with four replicates. Main plots (cultivars) were $6.10 \times 4.57 \mathrm{~m}$ with 15 rows spaced $30.48 \mathrm{~cm}$. Subplots (cutting intervals) were $4.57 \times 3.05 \mathrm{~m}$. During the first 390 days of experimentation, cutting intervals were 45 and 65 days. Thereafter, the 45-day interval was changed to 79 days and 
the subplots were cut at 65- and 79-day intervals during the final 316 days.

A treatment combination of $1 / 5$ cultivar Endeavour and $4 / 5$ D. milanjiana was simultaneously sown. The grass crowded out the legume by the end of the $3 \mathrm{rd}$ and 5th cutting at the 45- and 65-day intervals, respectively. These treatments were, therefore, excluded from the statistical analyses.

All stylo plots received $112 \mathrm{~kg} / \mathrm{ha} / \mathrm{yr}$ of $\mathrm{P}$ and $\mathrm{K}$ in a single application, while the grass received $3,360 \mathrm{~kg}$ per ha per yr of a 15-5-10 fertilizer; the appropriate amounts were applied after each cutting according to the cutting interval used.

A general cutting was done 134 days after planting (May 11, 1978); thereafter, cuttings were done at the specified intervals. The legumes were cut to a $20-\mathrm{cm}$ stubble height and the grass to one of $7 \mathrm{~cm}$ from the ground, with a Gravely ${ }^{3}$ sickle bar machine.

All the forage from each plot was weighed and removed. Samples were dried at $63^{\circ} \mathrm{C}$ for dry matter (DM) determinations and ground in a Wiley mill to pass through a $1-\mathrm{mm}$ screen. For each cutting interval, forage samples were composited by replications and wet digested with sulfuric acid (11), before determining $\mathrm{N}, \mathrm{P}$, and $\mathrm{K}$ with a Technicon auto analyzer; $\mathrm{Ca}$ and $\mathrm{Mg}$ by flame photometry (2). CP was calculated as $\mathrm{N} \times 6.25$.

The data for green forage (GF), DF, and CP yields and for DM contents were subjected to analysis of variance, and Duncan's multiple range test (13).

\section{RESULTS AND DISCUSSION}

All stylos were established well within 134 days after planting, but the grass required only 105 days. Establishment of cultivar Fine Stem was slower than that of the other cultivars. All stylo cultivars nodulated freely under the conditions of this experiment.

Table 2 shows mean DM contents and yields from nine cuttings at 45 days of growth from May 11, 1978 to June 25, 1979 and from six cuttings at 65 days from May 11, 1978 to June 5, 1979. At both cutting intervals, D. milanjiana far outyielded the six stylo cultivars in GF and DF, although at 45 days the grass exhibited the lowest DM content. Cultivar Fine Stem significantly exceeded the rest of the stylo cultivars in DF yield at both intervals. In GF yield, it did not significantly surpass cultivars Endeavour, Schofield or USDA PI 361877 at the 45-day interval nor any of the other stylo cultivars at the 65-day interval.

Cultivar Fine Stem presented a CP yield similar to D. milanjiana at

${ }^{3}$ Trade names in this publication are used only to provide specific information. Mention of a trade name does not constitute a warranty of equipment or materials by the Agricultural Experiment Station of the University of Puerto Rico, nor is this mention a statement of preference over other equipment or materials. 
TABLE 2.-Yields and dry matter contents of 6 forage legumes and 1 forage grass cut at 45- and 65-day intervals during a period of 405 and 390 days, respectively

\begin{tabular}{|c|c|c|c|c|c|c|c|c|}
\hline \multirow[b]{2}{*}{ Identification } & \multicolumn{4}{|c|}{ 45-day interval } & \multicolumn{4}{|c|}{ 65-day interval } \\
\hline & $\begin{array}{c}\text { Green } \\
\text { forage } \\
\text { yield }\end{array}$ & $\begin{array}{c}\text { Dry } \\
\text { matter } \\
\text { content }\end{array}$ & $\begin{array}{l}\text { Dry } \\
\text { forage } \\
\text { yield }\end{array}$ & $\begin{array}{l}\text { Crude } \\
\text { protein } \\
\text { yield }\end{array}$ & $\begin{array}{l}\text { Green } \\
\text { protein } \\
\text { yield }\end{array}$ & $\begin{array}{c}\text { Dry } \\
\text { matter } \\
\text { content }\end{array}$ & $\begin{array}{l}\text { Dry } \\
\text { forage } \\
\text { yield }\end{array}$ & $\begin{array}{c}\text { Crude } \\
\text { protein } \\
\text { yield }\end{array}$ \\
\hline & $\mathrm{kg} / \mathrm{ha}$ & $\%$ & $\mathrm{~kg} / \mathrm{ha}$ & $\mathrm{kg} / \mathrm{ha}$ & $\mathrm{kg} / \mathrm{ha}$ & $\%$ & $\mathrm{~kg} / \mathrm{ha}$ & $\mathrm{kg} / \mathrm{ha}$ \\
\hline Fine stem & $69,543 \mathrm{~b}^{1}$ & $27.2 \mathrm{a}$ & $18,522 \mathrm{~b}$ & 3,339 a & $71,196 \mathrm{~b}$ & $26.8 \mathrm{a}$ & $18,936 \mathrm{~b}$ & $3,174 \mathrm{a}$ \\
\hline Endeavour & $62,055 \mathrm{~b}$ & 25.9 a & $14,868 \mathrm{c}$ & $2,889 \mathrm{~b}$ & $62,202 \mathrm{~b}$ & $23.2 \mathrm{c}$ & $14,424 \mathrm{c}$ & 2,724 a \\
\hline Schofield & $57,258 \mathrm{~b}$ & 25.8 a & $13,806 \mathrm{~cd}$ & $2,718 \mathrm{~b}$ & $59,868 \mathrm{~b}$ & $25.9 \mathrm{ab}$ & $14,004 \mathrm{c}$ & $2,526 \mathrm{a}$ \\
\hline USDA PI 361877 & $56,187 \mathrm{~b}$ & $25.1 \mathrm{a}$ & $13,671 \mathrm{~cd}$ & $2,709 \mathrm{~b}$ & $53,826 \mathrm{~b}$ & $27.7 \mathrm{~b}$ & $12,894 \mathrm{c}$ & $2,453 \mathrm{a}$ \\
\hline USDA PI 279603 & $48,987 \mathrm{c}$ & $26.4 \mathrm{a}$ & $12,195 \mathrm{~d}$ & $2,367 \mathrm{c}$ & $56,928 \mathrm{~b}$ & $24.5 \mathrm{~b}$ & $14,100 \mathrm{c}$ & 2,562 a \\
\hline USDA PI 261266 & $54,351 \mathrm{c}$ & $26.2 \mathrm{a}$ & $13,374 \mathrm{~cd}$ & $2,250 \mathrm{c}$ & $54,696 \mathrm{~b}$ & $24.7 \mathrm{~b}$ & $13,104 \mathrm{c}$ & $2,454 \mathrm{a}$ \\
\hline USDA PI 299699 & 130,473 a & $24.1 \mathrm{~b}$ & $29,574 \mathrm{a}$ & $3,096 \mathrm{ab}$ & 133,938 a & $25.1 \mathrm{ab}$ & 29,920 a & $2,892 \mathrm{a}$ \\
\hline
\end{tabular}

${ }^{1}$ Means in the same column followed by one or more letters in common do not differ significantly at the $5 \%$ probability level. 
45 days and was superior to the other cultivars at this interval. All forages gave similar CP yields when cut at 65-day intervals (table 2).

Figure 1 shows the mean seasonal distribution of DF yields for stylo cultivars cut six times at 65-day intervals. Highest DF yields were obtained when cut on July 18, September 21, and November 27, whereas lowest yields were obtained on January 29, April 4, and June 5 cuttings. Similar results were reported by Vélez-Santiago et al. (14) for cultivar Endeavour in the same region of Puerto Rico. The low yields coincided with cool months and extended flowering of the stylo cultivars from October through April.

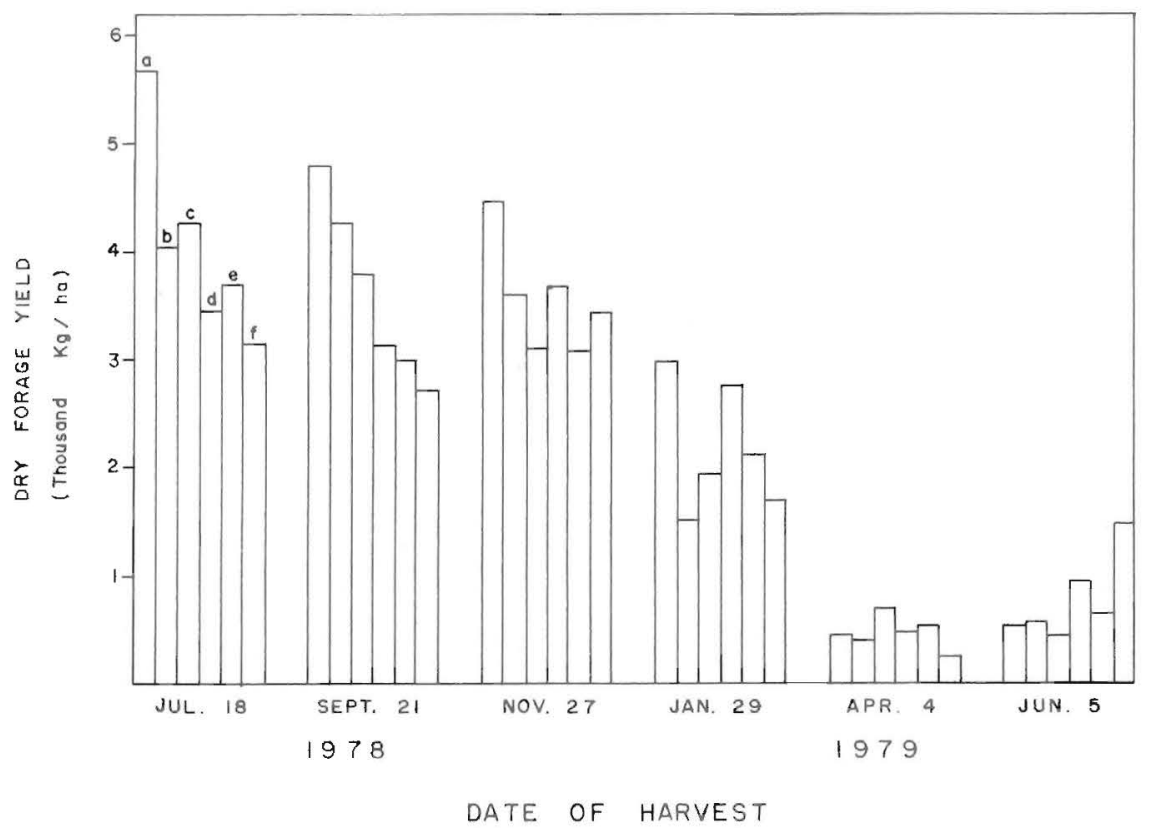

Fig. 1.-Seasonal dry forage yield distribution of six Stylosanthes cultivars: a. Finestem; b. Endeavour; c. USDA PI 279603; d. Schofield; e. USDA PI 26166; f. USDA PI 361877.

Table 3 shows GF, DF, and CP yields obtained from five cuttings (cut every 65 days) and from four cuttings (every 79 days) from June 1979 to May 1980. D. milanjiana again outyielded all stylo cultivars in GF and DF at both intervals. At 65 days, cultivars Fine Stem and USDA PI 361877 significantly outyielded cultivars Endeavour and USDA 279603 in DF yield. At this cutting interval, cultivars Fine Stem, Schofield, and USDA PI 361877 produced CP yields similar to that of $D$. milanjiana.

At the 79-day interval, all stylo cultivars gave similar yields in terms 
TABLE 3.-Yields and dry matter contents of 6 forage legumes and 1 forage grass cut at 65 - (5 cuttings) and 79-(4 cuttings) day intervals during a period of 316 and 325 days, respectively

\begin{tabular}{|c|c|c|c|c|c|c|c|c|}
\hline \multirow[b]{2}{*}{ Identification } & \multicolumn{4}{|c|}{ 65-day interval } & \multicolumn{4}{|c|}{ 79-day interval } \\
\hline & $\begin{array}{c}\text { Green } \\
\text { forage } \\
\text { yield }\end{array}$ & $\begin{array}{c}\text { Dry } \\
\text { matter } \\
\text { content }\end{array}$ & $\begin{array}{c}\text { Dry } \\
\text { forage } \\
\text { yield }\end{array}$ & $\begin{array}{l}\text { Crude } \\
\text { protein } \\
\text { yield }\end{array}$ & $\begin{array}{c}\text { Green } \\
\text { forage } \\
\text { yield }\end{array}$ & $\begin{array}{c}\text { Dry } \\
\text { matter } \\
\text { content }\end{array}$ & $\begin{array}{l}\text { Dry } \\
\text { forage } \\
\text { yield }\end{array}$ & $\begin{array}{l}\text { Crude } \\
\text { protein } \\
\text { yield }\end{array}$ \\
\hline & $\mathrm{kg} / \mathrm{ha}$ & $\%$ & $\mathrm{~kg} / \mathrm{ha}$ & $\mathrm{kg} / \mathrm{ha}$ & $\mathrm{kg} / \mathrm{ha}$ & $\%$ & $\mathrm{~kg} / \mathrm{ha}$ & $\mathrm{kg} / \mathrm{ha}$ \\
\hline Fine stem & $50,701 \mathrm{~b}^{1}$ & $31.15 \mathrm{a}$ & $14,643 \mathrm{~b}$ & $2,403 \mathrm{ab}$ & $36,313 \mathrm{~b}$ & $33.44 \mathrm{a}$ & $11,329 \mathrm{~b}$ & $1,796 \mathrm{a}$ \\
\hline Endeavour & $40,586 \mathrm{~b}$ & $28.92 \mathrm{~b}$ & $10,908 \mathrm{c}$ & $1,867 \mathrm{c}$ & $31,271 \mathrm{~b}$ & $33.73 \mathrm{a}$ & $9,552 \mathrm{~b}$ & $1,596 \mathrm{a}$ \\
\hline Schofield & $48,563 \mathrm{~b}$ & $27.11 \mathrm{~b}$ & $12,655 \mathrm{bc}$ & $2,523 \mathrm{ab}$ & $38,955 \mathrm{~b}$ & $31.41 \mathrm{ab}$ & $11,493 \mathrm{~b}$ & $2,000 \mathrm{a}$ \\
\hline USDA PI 361877 & $55,039 \mathrm{~b}$ & $28.74 \mathrm{bc}$ & $15,250 \mathrm{~b}$ & $2,912 \mathrm{a}$ & $37,427 \mathrm{~b}$ & $32.67 \mathrm{a}$ & $11,823 \mathrm{~b}$ & $1,973 \mathrm{a}$ \\
\hline USDA PI 279603 & $42,033 \mathrm{~b}$ & $27.84 \mathrm{~cd}$ & $11,297 \mathrm{c}$ & $2,151 \mathrm{bc}$ & $31,507 \mathrm{~b}$ & $31.79 \mathrm{ab}$ & $9,472 \mathrm{~b}$ & $1,606 \mathrm{a}$ \\
\hline USDA PI 261266 & $45,896 \mathrm{~b}$ & $27.24 \mathrm{bd}$ & $12,451 \mathrm{bc}$ & $2,303 \mathrm{bc}$ & $33,987 \mathrm{~b}$ & $31.96 \mathrm{ab}$ & $10,453 \mathrm{~b}$ & 1,781 a \\
\hline USDA PI 299699 & $111,791 \mathrm{a}$ & $25.12 \mathrm{e}$ & 27,910 a & $2,557 \mathrm{ab}$ & $85,596 a$ & $29.21 \mathrm{~b}$ & $25,046 \mathrm{a}$ & $2,057 \mathrm{a}$ \\
\hline
\end{tabular}

${ }^{1}$ Means in the same column followed by one or more letters in common do not differ significantly at the $5 \%$ probability level. 
TABLE 4.-Mineral composition of 6 forage legumes and 1 forage grass harvested at 45-, 65-, and 79-day intervals

\begin{tabular}{|c|c|c|c|c|c|}
\hline Identification & Nitrogen & Phosphorus & Potassium & Calcium & Magnesium \\
\hline & \multicolumn{5}{|c|}{$\%$} \\
\hline & \multicolumn{5}{|c|}{ 45-day interval } \\
\hline Fine stem & $2.91^{1}$ & .19 & 2.02 & 1.72 & .30 \\
\hline Endeavour & 3.12 & .27 & 2.20 & 1.54 & .33 \\
\hline Schofield & 3.17 & .27 & 2.51 & 1.54 & .28 \\
\hline USDA PI 361877 & 3.20 & .28 & 2.58 & 1.52 & .28 \\
\hline USDA PI 279603 & 3.12 & .25 & 2.49 & 1.56 & .29 \\
\hline USDA PI 261266 & 3.03 & .28 & 2.44 & 1.39 & .26 \\
\hline \multirow[t]{2}{*}{ USDA PI 299699} & 1.67 & .22 & 2.06 & .46 & .17 \\
\hline & \multicolumn{5}{|c|}{ 65-day interval } \\
\hline Fine stem & 2.68 & .18 & 1.87 & 1.71 & .30 \\
\hline Endeavour & 2.87 & .26 & 2.15 & 1.41 & .33 \\
\hline Schofield & 3.02 & .28 & 2.60 & 1.54 & .30 \\
\hline USDA PI 361877 & $3.0_{4}$ & .23 & 2.48 & 1.55 & .30 \\
\hline USDA PI 279603 & 2.92 & .26 & 2.43 & 1.53 & .28 \\
\hline USDA PI 261266 & 3.00 & .28 & 2.45 & 1.50 & .27 \\
\hline \multirow[t]{2}{*}{ USDA PI 299699} & 1.38 & .19 & 1.85 & .45 & .15 \\
\hline & \multicolumn{5}{|c|}{ 79-day interval } \\
\hline Fine stem & 2.57 & .18 & 1.20 & 1.81 & .29 \\
\hline Endeavour & 2.67 & .24 & 1.54 & 1.56 & .31 \\
\hline Schofield & 2.79 & .28 & 1.96 & 1.45 & .26 \\
\hline USDA PI 361877 & 2.73 & .23 & 1.95 & 1.33 & .24 \\
\hline USDA PI 279603 & 2.75 & .24 & 2.00 & 1.51 & .28 \\
\hline USDA PI 261266 & 2.73 & .25 & 1.90 & 1.48 & .28 \\
\hline USDA PI 299699 & 1.30 & .14 & 1.16 & .31 & .11 \\
\hline
\end{tabular}

${ }^{1}$ Mean of 4 replicates.

of GF, DF, and CP (table 3). In general, DF and CP yields tended to decrease as cutting interval increased from 65 to 79 days. A 65-day cutting interval seems most convenient for harvesting stylo cultivars under the conditions of the humid mountain region of Puerto Rico. At 45-day intervals, the stylo cultivars were invaded by weeds after eight harvests. On the other hand, extending the cutting interval to 79 days caused DF and CP yields to decrease.

Table 4 shows the $\mathrm{N}, \mathrm{P}, \mathrm{K}, \mathrm{Ca}$, and $\mathrm{Mg}$ contents of the six stylo cultivars and $D$. milanjiana. In general, the stylo cultivars were much richer in minerals than the grass, especially in $\mathrm{N}, \mathrm{Ca}$, and $\mathrm{Mg}$ contents. $\mathrm{N}$ and $\mathrm{K}$ tended to decrease as the cutting interval increased.

A severe outbreak of anthracnosis (Colletotrichum gloeosporioides Penz.) greatly reduced growth during the rainy months from August to November 1979. It ws observed that cultivars Fine Stem and Endeavour showed a better recovery after this attack than the other cultivars.

Plots of stylo cultivars subjected to the 45 -day cutting interval were 


\section{JOURNAL OF AGRICULTURE OF UNIVERSITY OF PUERTO RICO}

invaded to some extent by native grasses (mainly Cynodon dactylon cv. dactylon) after eight cuttings. This occurred least in cultivar Fine Stem and USDA PI 361877. These two accessions, therefore, appear to have the ability to compete with native grasses. Although a 65-day harvest interval seems the most convenient for stylo cultivars in the humid mountains of Puerto Rico, the 45-day interval was better for D. milanjiana.

In conclusion, the six stylo cultivars had good DF yields for a tropical legume without liming and a small amount of fertilization. These results confirm previous finding (14) that stylos are relatively productive in the humid mountains of Puerto Rico with minimum fertilization. Cultivars Fine Stem, Endeavour, Schofield, and USDA PI 361877 performed best in this study. However, D. milanjiana, with heavy fertilization, outyielded by far in annual DF yields the stylo cultivars. The CP content of the stylos was twice that of the grass. For this reason, all the stylos yielded similar annual CP yields as did the grass at the 45-, 65-, and 79-day intervals. A stylo- $D$. milanjiana mixture, with the grass heavily fertilized, do not seem to be a realistic alternative to increase forage yields and quality because $D$. milanjiana crowds and smothers the stylo. CaroCostas et al. (3) also reported a similar finding for a tropical kudzumolasses grass pasture in the same region.

\section{RESUMEN}

Un experimento en un suelo Ultisol de la región húmeda montañosa de Puerto Rico se realizó para evaluar el potencial de producción de forraje y proteina bruta de cinco selecciones de la leguminosa Stylosanthes guianensis, una de Stylosanthes gracilis y la gramínea Digitaria milanjiana USDA PI 299699.

En el primer período experimental, las forrajeras se cortaron nueve y seis veces cada 45 y 65 días, respectivamente. Durante el segundo período, se cortaron 5 y 4 veces cada 65 y 79 dias respectivamente. Las parcelas de leguminosas recibieron $112 \mathrm{~kg}$ por ha y año de fósforo y potasio en una sola aplicación. Las de la gramínea recibieron 3,360 kg por ha y año de un abono 15-5-10; se aplicó la cantidad indicada después de cada corte, según el intervalo asignado. Las parcelas no se regaron en ninguno de los períodos experimentales.

La gramínea $D$. milanjiana sobrepasó significativamente en producción de forraje verde y seco las seis selecciones de Stylo a los 3 intervalos de 45,65 y 79 días. La gramínea produjo 29,574 y $29,920 \mathrm{~kg} / \mathrm{ha}$ en 13.5 meses cuando se cortó cada 45 y 65 dias, respectivamente. A intervalos de 79 días, produjo $25,046 \mathrm{~kg}$ por ha en un período de 10.5 meses. Las leguminosas más productivas de forraje seco fueron la cultivar Fine Stem 
(IRFL-1416), S. guianensis USDA PI 361877 y las cultivares comerciales Endeavour y Schofield. La cultivar Fine Stem produjo rendimientos de 18,522 y $18,936 \mathrm{~kg} / \mathrm{ha}$ en 13.5 meses, que pueden considerarse altos para una leguminosa tropical. Cuatro de las cultivares produjeron casi tanta proteina bruta como la D. milanjiana al cortarse cada 45 días, mientras que a intervalos de corte de 65 y 79 días todos se acercaron a la gramínea en este criterio.

En la época lluviosa surgió un brote de antracnosis que redujo el crecimiento de las seis leguminosas, pero en menor grado a las cultivares Endeavour y Fine Stem.

Se sugiere cortar la leguminosa cada 65 dias. Al cortarse cada 45 días, los yerbajos tienden a invadirla después del año. A intervalos de 79 días, la leguminosa tiende a producir menos forraje y proteína bruta que cuando se corta cada 65 días. Se presenta el contenido en nitrógeno, fósforo, potasio, calcio y magnesio de las leguminosas y la gramínea para los tres intervalos de corte estudiados. En general, las cultivares arrojaron marcadamente mayores contenidos en nitrógeno, calcio y magnesio que la graminea D. milanjiana.

\section{LITERATURE CITED}

1. Alkamper, J. and Schultze-Kraft, R., 1979. The suitability of Stylosanthes species for improving pastures in the Savanna regions of Colombia, Plant Res. and Dev., 9: 2435.

2. Burriel-Marti, F. and Ramírez-Muñoz, J., 1960. Flame photometry, A manual of methods and application, 3rd rep, Elsevier Publ. Co., Amsterdam, Holland.

3. Caro-Costas, R. and Abruña, F., 1963. Effect of liming and fertilization on productivity and species balance of a tropical kudzu-molasses grass pasture under grazing management, J. Agric. Univ. P. R. 47 (4): 231-42.

4. Edye, L. A., Field, J. B. and Cameron, D. F., 1975. Comparison of some Stylosanthes species in the dry tropics of Queensland, Aust. J. Exp. Agric. Anim. Husb. 15 (76): 655-62.

5. — - - - - Bishop, H. G., Hall, R. L., Prinsen, J. H. and Walker, B., 1976. Comparison of some Stylosanthes species at three sites in central Queensland, Aust. J. Exp. Agric. Anim. Husb. 16 (82): 715-22.

6. Harding, W. A. T., 1972. The contribution of plant introduction to pasture development in the wet tropics of Queensland, Trop. Grassl. 6 (3): 191-9.

7. - and Cameron, D. G., 1972. New pasture legumes for the wet tropics, Queensl. Agric. J. 98 (8): 394-406.

8. McIvor, J. G., 1978. The effect of cutting interval and associate grass species on the growth of Stylosanthes species near Ingham, North Queensland, Aust. J. Exp. Agric. Anim. Husb. 18 (93): 546-53.

9. — Bishop, H. G., Walker, B. and Rutherford, M. T., 1979. The performance of Stylosanthes guianensis accessions at two sites in coastal north and central Queensland, Trop. Grassl. 13 (1): 38-44.

10. Paterson, R. T. and Horrell, C. R. 1981. Forage legumes in Santa Cruz, Bolivia, Trop. Anim. Prod. 6: 44-53. 


\section{JOURNAL OF AGRICULTURE OF UNIVERSITY OF PUERTO RICO}

11. Riera, A., 1955. The method of foliar diagnosis as applied to sugarcane, II, The chemical analyses of sugarcane-leaf samples, Agric. Exp. Stn. Univ. P. R. Bull. 123.

12. Rivera-Brenes, L., 1947. The utilization of grasses, legumes, and other forage crops for cattle feeding in Puerto Rico, I. Comparison of Guinea grass, Pará grass "Malojillo" and a mixture of Pará grass and tropical Kudzu as pasture crops, J. Agric. Univ. P. R. 31 (2): 180-9.

13. Snedecor, G. W. and Cochran, W. G., 1967. Statistical methods, 6th ed, The Iowa State Univ. Press, Ames, Iowa.

14. Vélez-Santiago, J., Sotomayor-Ríos, A., and Lugo-López, M. A., 1981. Potential of Stylosanthes guianensis as a forage crop in the humid mountain region of Puerto Rico, J. Agric. Univ. P. R. 65 (3): 232-40. 